\title{
Optimalisasi Siskohat dalam Meningkatkan Pelayanan Pendaftaran Jamaah Haji
}

\author{
Agvira Faiza Zulfa ${ }^{{ }^{*}}$, Irfan Sanusi $1^{1}$, Asep Iwan Setiawan $2^{2}$ \\ ${ }^{123}$ Jurusan Manajemen Dakwah, Fakultas Dakwah dan Komunikasi, UIN Sunan Gunung Djati, \\ Bandung \\ *Email:agvira.paiza@student.uinsgd.ac.id
}

\begin{abstract}
ABSTRAK
Penelitian ini bertujuan untuk mengetahui bagaimana proses optimalisasi siskohat yang dilakukan oleh kepala seksi Penyelenggaraan Haji dan Umrah Kementerian Agama Provinsi Jawa Barat terhadap pelayanan pendaftaran calon jamaah haji. Metode penelitian ini menggunakan metode deskriptif Teknik pengumpulan data dalam penelitian ini yaitu melalui observasi, wawancara, dan studi dokumentasi. Adapun analisis data dilakukan melalui penafsiran logika yang dihubungkan dengan konteks Manajemen Dakwah. Hasil penelitian menunjukkan bahwa: Pertama, standar kompenen hardware yang ditetapkan Seksi Penyelenggaraan Haji dan Umrah; Kedua, pembaruan sistem software siskohat dan memperbaiki beberapa bug yang dilakukan oleh Kepala Seksi Penyelenggaraan Haji dan Umrah dalam meningkatkan proses pelayanan; Ketiga, standar brainware yang ditetapkan oleh Kepala Seksi Penyelenggaraan Haji dan Umrah dalam meningkatkan pelayanan pendaftaran. Secara umum penelitian ini dapat disimpulkan bahwa optimalisasi siskohat dalam pelayanan pendaftaran jamaah yang dilakukan oleh Kepala Seksi Penyelenggaraan Haji dan Umrah ini sudah tepat, dengan adanya proses penetapa standar dan tindakan pembaruan program yang telah ditetapkan dapat berjalan dengan efektif dan lancar.
\end{abstract}

Kata Kunci: Optimalisasi; Siskohat; Pelayanan Pendaftaran Jamaah Haji

\section{ABSTRACT}

This study aims to find out how the process of optimization siskobat conducted by the bead section of Haij and Umrah Implementation of the Ministry of Religion of West Java Province to the registration service candidates for pilgrims. This research method using descriptive method Data collection techniques in this study is through observation, interviews, and documentation studies. The data analysis is done through the interpretation of logic that is connected with the context of Da'wah Management. The result of the research shows that: First, the standard of 
A. F. Zulfa, I. Sanusi, A.I. Setiawan

hardware component determined by the Section of Hajj and Umrah Implementation; Second, update siskohat software system and fix some bugs made by Head of Section of Hajj and Umrah Implementation in improving service process; Third, the standard brainware set by Head of Section of Hajj and Umrah Implementation in improving registration service. In general, this research can be concluded that the optimization siskohat in service registration of pilgrims conducted by the Head of Section of Haij and Umrah Implementation is already appropriate, with the process penyapa standard and program update actions that have been set can run effectively and smoothly.

Keywords: Optimization, Integrated Hajj Computerized System, Hajj Pilgrimage Service

\section{PENDAHULUAN}

Haji merupakan salah satu dari kelima aspek rukun Islam, yang mana tidak sempurna Islam seseorang yang mampu menunaikan haji sampai ia berhaji (Al'aqil, 1427 H: 7). Haji pada hakekatnya merupakan aktifitas suci yang pelaksanaanya diwajibkan oleh Allah kepada seluruh umat Islam yang telah mencapai istitho'ah (mampu), disebut rangkaian suci karena seluruh rangkaian kegiatannya adalah ibadah (Syariati, 2000: 1).

Haji dalam masyarakat Islam pada umumnya dianggap sebagai al-mu'tamar al-sanawi al-duali yang sangat efektif. Karena hampir setiap pelosok dunia setiap tahun terwakili untuk hadir di Makkah (Mustofa, 2005: 26). Ibadah haji merupakan wujud nyata persaudaraan antara muslim dunia. Haji merupakan mu'tamar tahunan dan silaturahmi akbar, di mana mereka dapat menukar pengalaman, menyatukan visi dan persepsi, program dan acuan memajukan Islam di negeri masing-masing setelah mereka kembali dari ibadah (Shihab, 2000: 32).

Ibadah haji adalah rukun Islam kelima. Kewajiban untuk berhaji minimal sekali dalam seumur hidup itu dibebankan hanya kepada seorang muslim yang mampu dalam arti luas, yaitu mampu secara jasmani maupun secara rohani. Ibadah haji juga merupakan kewajiban yang harus dilaksanakan oleh setiap umat Islam yang memenuhi syarat istitaah, baik secara finansial, fisik maupun mental. Haji pada hakikatnya merupakan aktifitas suci yang pelaksanaannya diwajibkan oleh Allah kepada seluruh umat Islam yang telah mencapai istitho'a (mampu), disebut aktifitas suci karena seluruh rangkaian kegiatannya adalah ibadah (Syari'ati, Haji, 2000: 1). Indonesia sebagai salah satu negara yang memiliki jumlah penduduk beragama Islam terbesar di dunia selalu menyelenggarakan haji setiap tahunnya. Dalam Undang-Undang Nomor 13 Tahun 2008 tentang Penyelenggaraan Ibadah Haji, mengatur mengenai rangkaian kegiatan pengelolaan pelaksanaan ibadah haji yang meliputi pembinaan, pelayanan, dan perlindungan jamaah haji yaitu untuk memberikan pembinaan, pelayanan, dan perlindungan bagi jamaah haji. Adapun tujuan dari penyelenggaraan ibadah haji yaitu untuk memberikan pembinaan, pelayanan, dan perlindungan yang sebaik- 
baiknya bagi jemaah haji sehingga jemaah haji dapat menunaikan ibadahnya sesuai dengan ketentuan ajaran agama Islam. Penyelenggaraan Ibadah haji dilaksanakan berdasarakan asas keadilan, profesionalitas, dan akuntabilitas dengan prinsip nirlaba (Undang-Undang Nomor 13 Tahun 2008 tentang Penyelenggaraan ibadah haji pasal 1 ayat 2 dan pasal 3).

Pelaksanaan ibadah haji di Indonesia secara nasional menjadi wewenang Kementerian Agama (Kemenag). Dalam kewenangan tersebut juga terkandung tanggung jawab yang besar karena dalam pelaksanaan ibadah haji diperlukan pelayanan yang baik. Pelayanan ibadah haji tidak hanya menyangkut kesejahteraan lahir dan batin jamaah haji, namun menyangkut nama baik dan martabat bangsa Indonesia di luar negeri, khususnya di Arab Saudi. Mengingat pelaksanaannya bersifat massal dan berlangsung dalam jangka waktu yang terbatas, maka penyelenggaraan ibadah haji memerlukan manajemen yang baik, agar penyelenggaraan ibadah haji tersebut dapat berjalan dengan tertib, aman, dan lancar (Dirjend. Pelayanan Haji dan Umroh, 2010: 11).

Adanya peningkatan pendaftaran jamaah haji dari tahun ke tahun yang begitu pesat, serta pembatasan jamaah haji yang berangkat ke Tanah Suci Saudi Arabia menyebabkan penumpukan calon jamaah haji yang semakin bertambah panjang. Peningkatan jumlah pendaftar yang mencapai angka 458.650 jiwa di wilayah Jawa Barat pada tahun 2017, menjadikan daftar tunggu (waiting list) keberangkatan ibadah haji ke Baitullah mencapai 19-20 tahun (Kantor Wilayah Kementrian Agama Provinsi Jawa Barat). Kondisi waiting list dari tahun ke tahun yang telah mencapai puluhan tahun tidak mungkin dilakukan dengan cara manual, konvensional, dengan mengandalkan tumpukan berkas ataupun menggunakan sistem komputer yang tidak terhubung oleh jaringan. Hal ini akan memperlambat kinerja lembaga pelayanan bagi publik di lembaga kementrian agama.

Peningkatan calon jamaah haji dari tahun ke tahun, menuntut Bidang Penyelenggaraan Haji dan Umroh Kantor Wilayah Kementerian Agama Provinsi Jawa Barat untuk senantiasa melakukan berbagai hal pembenahan, penataan dan perubahan. Bahkan bila perlu reform atau merekonstruksi struktur organisasi, Sumber Daya Manusia, serta Sistem Informasi dan Komputerisasi dalam upaya melakukan pembenahan peningkatan pelayanan bagi publik.

Sebagai penyelenggara dan pemberi layanan, Kantor Wilayah Kementrian Agama Provinsi Jawa Barat memiliki tanggung jawab penuh sebagai penyelenggara dan pemberi pelayanan kepada jamaah haji dengan mengeluarkan berbagai kebijakan yang menyangkut pelayanan ibadah haji mulai dari perumusan dan pelaksanaan, penyusunan norma-norma, standar operasional, prosedur, dan kriteria, bimbingan teknis, monitoring operasional ibadah haji serta evaluasi dalam pelayanan penyelenggaraan ibadah haji. 
Upaya untuk meningkatkan pelayanan haji terus dilakukan oleh Bidang Penyelenggaraan Ibadah Haji dan Umroh Kantor Wilayah Kementerian Agama Provinsi Jawa Barat dengan melakukan evaluasi terhadap hasil pelaksanaan penyelenggaraan haji dari tahun ke tahun yang kemudian ditindak lanjuti dengan penyempurnaan pola pelayanan untuk mengatasi kekurangan-kekurangan yang terjadi. Suatu langkah tepat yang telah diambil oleh Kementerian Agama dalam upaya meningkatkan pelayanan haji adalah dengan membangun suatu Sistem Informasi dan Komputerasi Haji Terpadu (SISKOHAT) yang terhubung dengan Kantor Wilayah Kementerian Agama serta Kementerian Agama seluh Kabupaten Kota di Indonesia. Sistem Informasi dan Komputerasi Haji Terpadu (SISKOHAT) merupakan suatu sistem pelayanan secara on-line dan real time antara Bank Penyelenggara Penerima Setoran (BPS BPIH) Ibadah Haji, Kantor Wilayah Kementerian Agama di 33 Provinsi dan kabupaten (termasuk Kabupaten Polewali Mandar Sulawesi Barat) dengan Host Pusat Komputer untuk penyimpanan seluruh database calon Jamaah Haji di Kementerian Agama Pusat yakni di Jakarta Pusat.

Sejauh ini yang peneliti dapatkan pada saat melakukan wawancara awal dengan pihak Kemenag Provinsi Jabar bahwa proses pengoptimalan siskohat dalam proses pelayanan pendaftaran jamaah haji dinilai belum maksimal. Namun dalam prakteknya masih terdapat permasalahan-permasalahan yang terjadi dilapangan salah satunya terkait dengan kurangnya aspek brainware yang melayani para pendaftar haji. Berangkat dari permasalahan ini maka dibutuhkan proses optimalisasi yang baik dan benar. Maka dari itu perlunya pimpinan yang bisa mengelola lembaga yang dinaunginya agar tingkat kedisiplinan pegawai lebih maksimal dalam mememahi uraian pekerjaannya dan pimpinan juga perlu kiranya mengetahui lebih jauh bagaimana manajemen pelayanan ibadah haji, yang artinya sistem manajemen yang sejatinya dapat menjalankan fungsi-fungsi merencana, mengorganisasi, mengarahkan dan mengawasi kegiatan penyelenggaraan haji demi terlaksananya penyelenggaraan ibadah haji yang aman, lancar, dan berjalan dengan baik (Pasal 5 Undang-Undang No 17 Tahun 1999 tentang tentang Penyelenggaran Ibadah Haji). Penyelenggaraan ibadah haji akan berjalan dengan baik apabila didukung dengan sistem komputerisasi dalam pendaftaran yang baik agar dapat mencapai tujuan yang diharapkan.

Pembangunan Sistem Informasi dan Komputerasi Haji Terpadu (SISKOHAT) tidak hanya dirancang untuk melayani pendaftaran haji secara online, lebih jauh lagi mencakup dukungan terhadap seluruh prosesi penyelenggaraan haji mulai dari pendaftaran calon haji, pemrosesan dokumen haji, persiapan keberangkatan (embarkasi), monitoring operasional di Tanah Suci sampai pada proses kepulangan ke tanah air (debarkasi).

Untuk itu telah disiapkan pula infrastruktur pendukung di Kantor Wilayah Kementerian Agama 33 Provinsi, salah satunya di Kantor Wilayah Kementerian 
Agama Provinsi Jawa Barat yang mencakup 13 embarkasi serta rencana pembangunan infrastruktur di Kantor Kementerian Agama Daerah Tingkat-II dan infrastruktur di Arab Saudi yang akan On-line ke Pusat SISKOHAT di Jakarta, sehingga secara keseluruhan Sistem Informasi dan Komputerasi Haji Terpadu (SISKOHAT) akan menjadi suatu Sistem Informasi yang terintegrasi dalam satu database untuk mendukung dan meningkatkan pelayanan penyelenggaraan ibadah haji terutama dalam aspek pengelolaan informasi haji.

Sistem komputerisasi yang terbagi menjadi 3 bagian yakni, hardware, software dan brainware, menjadi peran penting dalam pelayanan jamaah haji, semakin baiknya ketiga sistem tersebut semakin bagus juga pelayanan yang akan diberikan kepada jamaah haji.

Setiap lembaga pasti mempunyai sistem informasi dan komputerisasi yang membantu memudahkan menjalankan setiap aktivitas yang ada dalam lembaga tersebut. Sebuah Sistem Informasi dan Komputerisasi merupakan alat yang harus ada di sebuah lembaga terpenting yang memiliki pengaruh sangat besar terhadap kesuksesan sebuah lembaga atau kesuksesan sebuah kegiatan. Tanpa mesin canggih, lembaga dapat terus beroperasi secara manual. Maka dari itu pada saat penyelenggaraan ibadah haji khususnya proses pelayanan pendaftaran jamaah haji lembaga membutuhkan sistem yang dapat membantu mencapai tujuan.

Berdasarkan data diatas, kita dapat melihat bahwa dalam penyelanggaraan ibadah haji dibutuhkan persiapan yang matang dan dibantu dengan manajemen yang baik yang dilakukan oleh setiap unsur manajemen (machine/mesin) agar tidak terjadi lagi permasalahan yang begitu kompleks pada saat eksekusi dilapangan. Maka dari itu, penulis tertarik untuk meneliti tentang "Optimalisasi Siskohat Dalam Pelayanan Pendaftaran Jamaah Haji di Kanwil Kemenag Jabar".

Penelitian ini dilakukan di Kementrian Agama Provinsi Jawa Barat Bidang Haji dan Umroh yang beralamat di Jl. Sudirman No. 24 Bandung. Pengambilan lokasi di daerah tersebut mengingat besarnya kemungkinan penelitian dapat dilaksanakan yaitu dengan melihat data-data yang dibutuhkan dalam penelitian ini tersedia dan untuk mengumpulkan data-data juga tidak terlalu sulit. Dilihat dari pertimbangan kesesuaian dengan latar belakang akademik penyusun, penelitian ini tepat dilaksanakan mengingat ada kolerasi antara penyusum yang sedang studi tentang manajemen dakwah dengan pengambilan judul dan objek penelitian tersebut.

Adapun pertanyaan pada penelitian ini yaitu: 1) Bagaimana Unit Hardware SISKOHAT dalam pelayanan pendaftaran jamaah haji reguler di Kementiran Agama Provinsi Jawa Barat. 2) Bagaimana Unit Software SISKOHAT dalam pelayanan pendaftaran jamaah haji reguler di Kementrian Agama Provinsi Jawa Barat. 3) Bagaimana Unit Brainware SISKOHAT dalam pelayanan pendaftaran 
jamaah haji reguler di Kementrian Agama Provinsi Jawa Barat. Metode penelitian yang digunakan oleh peneliti yaitu metode penelitian deskriptif Metode deskriptif yaitu suatu rumusan masalah yang memandu penelitian untuk mengeksplorasi atau memotret situasi sosial yang akan diteliti secara menyeluruh, luas, dan mendalam. Metode ini bertujuan untuk melukiskan secara sistematis fakta atau karakteristik populasi tertentu atau bidang tertentu secara faktual dan cermat. Dalam proses pengumpulan datanya ia lebih menitikberatkan pada observasi lapangan dan suasana ilmiah, dengan mengamati gejala-gejala, mencatat, mengategorikan, dan sedapat mungkin menghindari pengaruh kehadirannya untuk menjaga keaslian gejala yang diamati. (Rakhmat, 1985: 3435). Dengan menggunakan metode ini peneliti akan menganalisis hasil pengumpulan data melalui observasi dan wawancara dengan kepala seksi Penyelenggaraan Haji dan Umrah Kementerian Agama Provinsi Jawa Barat.

\section{LANDASAN TEORITIS}

Optimalisasi banyak juga diartikan sebagai ukuran dimana semua kebutuhan dapat dipenuhi dari kegiatan-kegiatan yang dilaksanakan. Menurut Winardi (1996: 363), optimalisasi adalah ukuran yang menyebabkan tercapainya tujuan. Secara umum optimalisasi adalah pencarian nilai terbaik dari yang tersedia dari beberapa fungsi yang diberikan pada suatu konteks.

Sistem adalah sekumpulan unsur / elemen yang saling berkaitan dan saling mempengaruhi dalam melakukan kegiatan bersama untuk mencapai suatu tujuan. Contoh : 1) Sistem Komputer terdiri dari Software, Hardware, dan Brainware. 2) Sistem Akuntansi.

Suatu sistem adalah jaringan kerja prosedur-prosedur yang saling berhubungan, berkumpul bersama-sama untuk melakukan suatu kegiatan atau menyelesaikan suatu sasaran tertentu (Jogiyanto, 1999: 1) Menurut Murdik (2002: 68) bahwa sistem adalah seperangkat elemen yang membentuk kegiatan atau suatu prosedur atau bagian pengolahan yang mencari suatu tujuan-tujuan bersama dengan mengoperasikan data atau barang pada waktu tertentu untuk menghasilkan informasi atau energi atau barang.

Menurut Sigit (1999: 35) bahwa sistem memiliki komponen-komponen diantaranya: Penghubung sistem, batasan sistem lingkungan luar, masukan, keluaran, dan tujuan. Menurut Budiarti (1999: 22) menyatakan bahwa elemen sistem adalah bagian tang terkecil yang teridentifikasi, ini merupakan penyusunan dari sistem.

Suatu sistem mempunyai karakteristik atau sifat-sifat yang tertentu, yaitu mempunyai komponen, batas sistem, lingkungan luar sistem, penghubung, masukan, keluaran, tujuan (Jogiyanto, 1999: 3). Adapun pengertian dari masingmasing karakteristik Sistem tersebut adalah sebagai berikut : a) Komponen Sistem, Suatu sistem terdiri dari sejumlah komponen yang saling berinteraksi, 
yang artinya saling bekerja sama membentuk satu kesatuan; b) Batasan Sistem, Batasan sistem (boundary) merupakan daerah yang membatasi antara suatu dengan Sistem yang lainnya atau dengan lingkungan luarnya; c) Lingkunagan Luar Sistem, Lingkungan luar sistem (envronment) dari suatu sistem adalah apapun diluar batas dari sistem yang mempengaruhi oprerasi system; d) Penghubung Sistem, Penghubung (interface) merupakan media penghubung antara satu sub sistem dengan sub sistem yang lainya; e) Masukan Sistem, Masukan (imput) energi yang dimasukkan ke dalam sistem. Masukan dapat berupa masukan perawatan (maintenance input) dan masukan sinyal (signal input). Maintenance input adalah energi yang dimasukkan supaya sistem tersebut dapat beroperasi. Signal input adalah energy yang diproses untuk didapatkan keluaran; f) Keluaran Sistem, Keluaran (output) adalah hasil dari energi yang diolah dan diklasifikasikan menjadi keluaran yang berguna dan sisa pembuangan; g) Pengolahan Sistem, Suatu sistem dapat mempunyai suatu bagian pengolahan yang akan merubah masukan menjadi keluaran; h) Sasaran atau Tujuan Sistem, Sasaran dari sistem sangat menentukan sekali masukan yang dibutuhkan sistem dan keluaran yang dihasilkan sistem. Suatu sistem pasti mempunyai tujuan atau sasaran, kalau tidak mempunyai sasaran maka operasi sistem tidak ada gunanya. Sasaran dari sistem sangat menentukan sekali masukan yang dibutuhkan sistem dan keluaran yang akan dihasilkan sistem. Suatu sistem dikatakan berhasil bila mengenai sasaran atau tujuannya.

Komputerisasi adalah kegiatan pengolahan data yang sebagian besar prosesnya dilakukan menggunakan komputer, yang sudah terprogram dengan berbagai program yang akan menangani suatu aplikasi. Kegiatan komputerisasi adalah sebuah kegiatan pengolahan data dalam rangka menghasilkan informasiinformasi penting bagi manajemen, agar yang bersangkutan mampu mengendalikan perusahaan yang menjadi tanggung jawabnya menjadi lebih baik.

Sistem kerja komputer pada hakekatnya sinkron dengan proses berlangsungnya sistem informasi manajemen yang meliputi kegiatan-kegiatan, pengumpulan data (input), pengolahan data (processing), pemyajian informasi hasil pengolahan (output). (Effendy, 1989: 122).

Ada tiga aspek dasar dalam sistem pengolahan data secara elektroniks dengan mesin komputer itu, yaitu aspek, hardware (peralatan), software (prosedur), dan brainware (personalia). (Effendy, 1989: 124).

Hardware adalaha seluruh peralatan yang diperlukan untuk mengoperasikan suatu sistem komputer. Untuk dapat terlaksananya proses komputerisasi, maka sebagai konsekuesinya perlatan komputer yang akan digunakan harus ada. Ini tidak berarti bahwa sebuah perusahaan atau instansi lainnya yang akan menyelenggarakan komputerisasi itu harus memiliki peralatannya sendiri. Dapat diusahakan dengan jalan lain, misalnya dengan menyewa, baik seluruh faset 
maupun sebagian (Effendy, 1989: 125).

Software adalah seluruh faset dari sistem pengolahan data dari luar mesin komputer dan peralatan lainnya yang termasuk hardware. Tanpa software, proses komputerisasi tidak mungkin berjalan. Karena software ini merupakan inti dari system ini (Effendy,1989: 126).

Brainware adalah aspek manusia yang menangani proses komputerisasi. Bahwa aspek ini penting, karena kesalahan informasi yang dihasilkan mesin komputer seringkali disebabkan faktor personalia yang menanganinya, baik yang menangani aspek hardware maupun aspek software. Unit atau bagian dari mesin komputer terbagi menjai tiga bagian, Input Unit (pembaca data), Processing Unit (unit pusat pengolah), dan Output Unit (unit penghasil) (Effendy, 1989: 127-128).

Input Unit adalah data yang merupakan bahan mentah harus dirubah atau dialihkan terlebih dahulu ke dalam bentuk khusus yang dapat dibaca oleh komputer dengan dimasukannya ke dalam alat yang disebut Input Device. Processing atau pengolahan dilakukan oleh Central Processor atau kadang-kadang disebut juga Central Processing Unit (CPU), yang dalam sistem komputer merupakan hatinya, ini terdiri dari sejumlah unsur yang meskipun bervariasi di antara mesin komputer yang satu dengan yang lainnya, fungsinnya sama. Tiga unsur penting dalam Central Processor tersebut ialah : primary storage, arithmetic-logic, dan control. Output Unit yakni hasil processing disajikan melalui alat yang dinamakan output device yang dapat berbentuk "print out", pape tape, magnetic disk, magnetic tape, dan lain-lain (Effendy, 1989: 129-132).

Sistem Komputerisasi Haji Terpadu yang selanjutnya disebut SISKOHAT adalah sistem pengelolaan data dan informasi penyelenggaraan ibadah haji. SISKOHAT merupakan suatu sistem pelayanan secara on-line dan real time antara Bank Penerima Setoran Biaya Perjalanan Ibadah Haji (BPS BPIH), Kantor Wilayah Kementerian Agama Provinsi, Kantor Kementerian Agama Kabupaten atau Kota se Indonesia dengan pusat.

Sistem Komputerisasi Haji Terpadu merupakan sarana menumbuh kembangkan sistem pelayanan pendaftaran haji yang bersifat manual ke arah automatic melalui pemanfaatan teknologi informasi dan komunikasi yang dilakukan di Tanah Air maupun di Arab Saudi.

Adapun manfaat dan kemudahan yang ditawarkan Sistem Komputerisasi Haji Terpadu dalam penyelenggaraan ibadah haji dan umroh, antara lain Pada waktu yang bersamaan (real time) langsung dapat dihitung jumlah total dana keuangan setoran BPIH. Pertama, Pendaftaran haji dapat dilakukan sepanjang tahun (non stop), Kedua, Ketersediaan database jamaah haji yang semakin terstruktur, Ketiga, Kemudahan dan kecepatan layanan informasi tentang posisi dan status jamaah haji kepada publik.

Tujuan dibentuknya Sistem Komputerisasi Haji Terpadu (SISKOHAT) antara lain. Pertama, Agar calon jamaah haji dan masyarakat dapat memahami 
semua kebijakan pemerintah yang ada kaitannya dengan pembinaan dan penyelenggaraan ibadah haji di Indonesia dan Arab Saudi, Kedua, Untuk memberikan pelayanan informasi haji kepada calon jamaah haji, jamaah haji, dan masyarakat luas, Ketiga, Untuk memberikan pelayanan informasi haji kepada masyarakat secara profesional sehingga informasi dapat disampaikan secara cepat, tegas, dan akurat, Keempat, Untuk meningkatkan wawasan dan pengetahuan calon jamaah haji dan masyarakat dalam melaksanakan ibadah haji sehingga akan tercipta jamaah haji yang berwawasan dan mandiri, Kelima, Agar calon jamaah haji dan masyarakat dapat mengakses baik langsung ataupun tidak langsung semua data dan informasi tentang perhajian, Keenam, Agar calon jamaah haji dan masyarakat dapat mengetahui program atau kegiatan yang sudah atau akan berlangsung menyangkut proses persiapan haji di Indonesia dan Arab Saudi, Ketujuh, Untuk mengadakan pertukaran berita perhajian antar pusat informasi haji yang ada di wilayah kota, wilayah provinsi, dan wilayah informasi pusat, Kedelapan, Sebagai bahan pengambil kebijakan bagi para pimpinan dan sektor terkait untuk kelancaran pembinaan haji.

Pelayanan dalam Kamus Besar Bahasa Indonesia berasal dari kata layan yang diartikan dengan; membantu menyiapkan (mengurus) apa-apa yang diperlukan seseorang (PBDPN, 2008: 826). Menurut Kotler dalam Fajar Laksana (2008: 85), pelayanan adalah setiap tindakan atau kegiatan yang dapat ditawarkan oleh satu pihak kepada pihak lain, yang pada dasarnya tidak berwujud dan tidak mengakibatkan kepemilikan apapun Prinsip Pelayanan.

Menurut keputusan MENPAN Nomor 63 Tahun 2004 dikutip Ratminto dan Atik Septi Winarsih bahwa standar pelayanan sekurang-kurangnya meliputi (Ratminto dan Atik Septi, 2015: 24). Pertama, Prosedur Pelayanan yang dibakukan bagi pemberi dan penerima pelayanan termasuk pengaduan, Kedua, Waktu Penyelesaian yang ditetapkan sejak saat pengajuan permohonan sampai dengan penyelesaian pelayanan, Ketiga, Biaya Pelayanan termasuk rinciannya yang ditetapkan dalam proses pemberian pelayanan, Keempat, Produk Pelayanan yang akan diterima sesuai dengan ketentuan yang telah ditetapkan, Kelima, Sarana dan Prasarana pelayanan yang memadai oleh penyelenggara pelayanan, Keenam, Kompetensi Petugas Pemberi Pelayanan harus ditetapkan dengan tepat berdasarkan pengetahuan, keahlian, keterampilan, sikap dan perilaku yang dibutuhkan.

Pendaftaran adalah pencatatan nama, alamat, dan lain-lain dalam daftar (perihal mendaftar (Departemen dan Kebudayaan Indonesia, 2005: 179). Setiap penyelenggaraan pelayanan publik harus memiliki standar pelayanan dan dipublikasikan sebagai jaminan adanya kepastian bagi penerima pelayanan (Sanusi :2018). Standar pelayanan merupakan ukuran yang dibakukan dalam penyelenggaraan pelayanan publik yang diwajibkan ditaati oleh pemberi dan atau 
penerima pelayanan (Ratminto dan Atik Septi, 2015: 23).

Ibadah haji merupakan rukun Islam yang kelima yang merupakan salah satu kewajiban umat Islam dunia untuk menjalankannya bagi mereka yang mampu. Secara bahasa, kata haji berasal dari bahasa Arab, hajj yang berarti ziarah. Dalam hal ini adalah ziarah ke tempat-tempat yang diagungkan oleh agama Islam, yakni Baitullah Makkah dan Madinah, tepatnya adalah menziarahi ka'bah dengan syarat dan rukun tertentu (Ardani, 2008: 39).

Jamaah haji adalah warga negara Indonesia yang beragama Islam dan telah mendaftarkan diri untuk menunaikan Ibadah Haji sesuai dengan persyaratan yang ditetapkan (UU No.13 Tahun 2008: 2). Jamaah haji adalah seseorang atau sekelompok umat Islam yang akan menunaikan ibadah haji ke tanah suci dan memiliki kemampuan untuk melakukan pembayaran, seorang customer yang menginginkan pelayanan prima dan mempunyai kebebasan untuk menentukan apa yang dipilihnya sesuai dengan kemampuan dan tingkat pelayanan yang dikehendaki dan juga memenuhi rukun, syarat, wajib, sunah dan semua persyaratan untuk menunaikan ibadah haji (Nidjam, 2004: 11).

Jamaah haji adalah seorang muslim yang memiliki niat menunaikan ibadah haji dan kemampuan secara fisik untuk menjalani ritual peribadatan dan menyediakan pembiayaan perjalanan. Dapat disimpulkan bahwa jamaah haji adalah jamaah yang sedang menunaikan ibadah haji atau telah selesai menunaikan ibadah haji pada tahun bersangkutan (baik yang mengikuti Kelompok Bimbingan Ibadah Haji (KBIH) maupun Pemerintah) (Aziz, 2007: 13)

Penyelenggaraan ibadah haji merupakan salah satu icon Kementerian Agama. Bagi sebagian orang, keberhasilan kinerja Kementerian Agama kerap hanya diukur sejauhmana Kementerian ini sukses menyelenggarakan pengelolaan ibadah tahunan tersebut. Haji adalah salah satu rukun Islam yang kelima yang diwajibkan Allah SWT kepada orang-orang yang mampu menunaiknannya, yakni memliki kesanggupan biaya serta sehat jasmani dan rohani untuk melakukan perintah tersebut. Kewajiban ibdah haji hanya sekali seumur hdup. Kewajiban ini baru disyariatkan pada tahun ke-6 hijriyah, setelah Rasulullah SAW hijrah ke Madinah. Nabi sendiri hanya sekali mengajarkan haji yang kemudian dikenal dengan sebutan Haji Wada'. Tak lama setelah itu, beliau wafat.

Beberapa keutamaan dan hikmah ibadah haji, diantaranya: 1) Mengajarkan ibadah haji adalah pekerjaan yang sangat mulia dan sangat terpuji, 2) Ibadah haji memberi kesan dan pesan terhadap perjalanan kehidupan seseorang., 3) Ibadah haji merupakan manifestasi ketundukan kepada Allah SWT, 4) Melaksanakan ibadah haji merupakan ungkapan syukur atas nikmat harta dan kesehatan, 5) Haji menempa jiwa agar memiliki semangat juang tinggi. Segala kesulitan yang dihadapi sejak dari tanah air hingga ditanah suci dan kembali lagi ke tanah air 
merupakan tantangan yang harus dihadapi seorang haji yang dengan itu, ia belajar sabar, tabah, kuat, disiplin, dan terdorong berakhlak mulia, 6) Haji dapat menjadi pemersatu antar umat Islam sedunia, 7) Para jamaah haji adalah delegasi Allah SWT.

Haji merupakan sebuah ritual ibadah istimewa yang tidak semua orang berkesempatan untuk melakukannya. Haji pada hakikatnya merupakan aktifitas suci yang pelaksanaannya diwajibkan oleh Allah kepada seluruh umat Islam yang telah mencapai istitho'a (mampu), disebut aktifitas suci karena seluruh rangkaian kegiatannya adalah ibadah (Syari'ati, Haji, 2000:1). Haji adalah suatu ibadah yang dilakukan dengan mengunjungi Ka'bah dan dilakukan pada waktu tertentu dengan syarat-syarat yang telah ditentukan atau ditetapkan. Kesemuanya itu dilakukan dalam rangka menaati perintah Allah SWT., dan mencapai rida-Nya. Ibadah haji tidak dilakukan di sembarang tempat, waktu, dan perbuatan. Jika tidak dilakukan pada tempat, waktu, dan tidak memenuhi ketentuannya, bukanlah haji.

Tentang syarat-syarat wajibnya haji itu menurut Tata Sukayat (2016:13) ialah : (1) Islam, (2) Baligh, (3) Berakal, (4) Merdeka, (5) Kuasa (mampu), (6) Sehat badannya, orang sakit, atau lemah bisa diwakilkan kepada orang lain apabila ia mempunyai cukup harta, (7) Ada kendaraan yang dapat mengangkut untuk pergi ke Makkah, (8) Keamanan dalam perjalan terjamin, (9) Memiliki bekal yang cukup bagi dirinya dan keluarganya sampai kembali dari haji, (10) Bagi wakita, harus bersama muhrim atau wanita lain uang mempunyai muhrim.

\section{HASIL DAN PEMBAHASAN}

Penelitian ini dilakukan di Kementerian Agama Provinsi Jawa Barat. Rute menuju Kementerian Agama Kota Sukabumi ini dapat ditempuh menggunakan kendaraan roda dua maupun roda empat. Lokasi Kementerian Agama Provinsi Jawa Barat ini cukup mudah ditemukan karena berada di area perkotaan.

Kementerian Agama Provinsi Jawa Barat merupakan instansi vertikal kementerian agama, dimana Kementerian Agama Provinsi Jawa Barat ini mendukung pelaksanaan tugas dan fungsi Kementerian Agama dalam meningkatkan pelayanan pemerintah terhadap masyarakat dalam memberikan pembinaan keagamaan. Dalam upaya memberikan pelayanan, para pegawai harus melaksanakan tugas pokok dan fungsi Kementerian Agama dalam wilayah Provinsi berdasarkan kebijakan Kepala Kantor Wilayah Kementerian Agama dan ketentuan perundang-undangan yang berlaku. Para pekerja di Kementerian Agama Provinsi Jawa Barat ini mayoritasnya adalah ASN atau Pegawai Negeri Sipil (PNS) maka dari itu setiap Pegawai Negeri Sipil harus memiliki pakta integritas agar para pegawai dapat bertanggung jawab terhadap tugasnya masingmasing dan dengan adanya pakta integritas ini dapat mengantisipasi tindakan 
korupsi, kolusi, dan nepotisme yang mungkin sewaktu-waktu dapat dilakukan oleh para pegawai, selain memiliki pakta integritas para pegawai disini juga harus mengacu pada kode etik pns.

Pada dasarnya setiap lembaga atau organisasi selalu melakukan proses pembaruan dan pengoptimalan karena proses pembaruan unsur sistem ini merupakan tahapan-tahapan di dalam melaksanakan kegiatan program kerja pada suatu lembaga. Proses pengoptimalan yang baik akan memastikan tujuan yang telah ditetapkan dari awal kepengurusan atau setelah pembentukan lembaga dapat tercapai. Kementerian Agama Provinsi Jawa Barat Seksi Penyelenggaraan Haji dan Umrah khususnya bagian siskohat memerlukan pengoptimalan yang dilakukan oleh kepala seksi dalam pencapaian tujuan, pengoptimalan dapat dianggap sebagai sebuah pengukuran dan perbaikan terhadap sistem yang sewaktu-waktu bisa terjadi error. Saat melakukan pengoptimalan Seksi PHU khususnya yang berada di bagian siskohat melakukan pengecekan terhadap bagian sistem baik itu hardware, software, dan brainware. Jadi pengoptimalan yang dilakukan oleh Seksi PHU khususnya bagian siskohat dilakukan dengan pengecekan setiap minggunya "maintenance sistem".

Hasil dari penelitian yang dilakukan di Kementerian Agama Provinsi Jawa Barat khususnya di seksi penyelenggaraan haji dan umrah, peneliti mendapatkan hasil bahwa optimalisasi yang dilakukan oleh seksi penyelenggaraan haji dan umrah ini sangat baik, sehingga dapat membawa dampak baik dalam proses peningkatan pelayanan pendaftaran bagi jamaah haji, seksi penyelenggaraan haji dan umrah ini selalu melakukan pembaruan dan pengecekan tiap minggunya sehingga sistem informasi dan komputerisasi disana menjadi lebih optimal, karena prioritas utama dari mereka itu adalah pemberian pelayanan prima kepada para jamaah serta mengimplementasikan kode etik dan menjalankan apa yang tertulis pada pakta integritas mereka sebagai seorang pegawai negeri sipil.

Proses pengoptimalan yang dilakukan oleh Kepala Seksi PHU ini mengacu pada beberapa tahapan, dimana tahapan-tahapan tersebut dilakukan agar proses pengoptiamal berjalan efektif dan efisien. Adapun tahapan pelaksanaan pengawasan yang dilakukan oleh Kepala Seksi Penyelenggaraan Haji dan Umrah yaitu: Keterkaitan unsur-unsur Komputerisasi yakni, Hardware, Software, dan Brainware, dalam SISKOHAT dinilai sudah baik dengan adanya perubahan-perubahan atau Update baik itu dari segi Hardware, Software, maupun Brainwarenya.

\section{Unit Hardware}

Tahap optimalisasi pertama ditinjau dari segi Hardwarenya, menurut Onong Ucthjana Effendy (1989: 125) Hardware adalah seluruh peralatan yang diperlukan untuk mengoperasikan suatu sistem komputer. Untuk dapat terlaksananya proses komputerisasi, maka sebagai konsekuesinya perlatan 
komputer yang akan digunakan harus ada. Ini tidak berarti bahwa sebuah perusahaan atau instansi lainnya yang akan menyelenggarakan komputerisasi itu harus memiliki peralatannya sendiri. Dapat diusahakan dengan jalan lain, misalnya dengan menyewa, baik seluruh faset maupun sebagian.

Untuk menyimpan beberapa data jamaah haji yang tiap taun meningkat dibutuhkan hardware yang bagus dan tempat penyimpanan yang besar, karena menurut Edy Winarno (2010: 62) bahwa ketika hardware yang data penyimpananya besar akan semakin besar juga data yang bisa disimpan.

Hardware, SISKOHAT telah beberapa kali mengupdate komponenkomponen Harrdware. Hardware yang di update berdasarkan kebutuhan pelayanan bagi jamaah haji baik reguler maupun khusus, seperti komponen RAM (Random Acces Memory), Processor, dan juga Harddisk sebagai media penyimpanan data yang harus besar karena sebagai daya tampung data pada sebuah Sistem Komputer. Dengan semakin bagusnya Hardware dalam sebuah komputer, maka proses penginputan data akan semakin cepat, dan dapat memudahkan user SISKOHAT dalam melayani pendaftaran jamaah haji.

Melihat spesifikasi di atas bahwa Sistem Hardware Siskohat benar-benar serius dalam melakukan Pelayanan Pendaftaran Jamaah Haji, komponen yang bagus menunjang semakin cepat dan efektifnya sebuah pelayanan.

Menurut hasil wawancara dengan bapak Hasfi selaku pegawai siskohat tanggal 30 Maret 2018, beliau mengatakan:

“....Untuk unit hardware disini kami selalu melakukan pengecekan atau proses maintenance tiap minggunya, kami tidak menunggu hardware ada masalah baru di cek, tapi kami selalu melakukan pengecekan tiap minggunya ada atau tanpa adanya masalah, selain itu untuk menjaga performa hardware kami selalu melakukan pembersihan perangkat agar tidak kotor dan kinerja perangkat tersebut bisa lebih efektif, dan untuk pembaruan perangkat kami selalu melihat update-update hardware terbaru di internet."

Dari hasil wawancara diatas bisa ditarik kesimpulan bahwa ada beberapa tindakan yang dilakukan oleh pegawai siskohat untuk mengoptimalkan perangkat hardware. Pertama, Melakukan pengecekan atau maintenance hardware setiap minggunya, baik ketika ada masalah maupun tidak, tindakan rutin ini bisa menjaga performa hardware dan daya tahanya akan semakin lama.

Kedua, Melakukan pembersihan pada perangkat-perangkat hardware supaya terhindar dari debu dan kotoran lainnya, tindakan ini dilakukan karena, ketika hardware kotor daya tahan bardware akan mudah rusak dan mengakibatkan kinerja hardware jadi lamban.

Ketiga, Tindakan Upgrade perangkat Hardware, pegawai siskohat selalu melihat dan mencari tahu/browsing ke internet tentang perangkat hardware yang 
terbaru, agar kualitas hardware siskohat bisa lebih update dan lancar dalam menampung beberapa data jamaah haji.

\section{Unit Software}

Peranan SISKOHAT sangat penting dalam menunjang tercapainya peningkatan pelayanan. Dengan optimalnya sebuah sistem yang terintegrasi yang menkomodir proses layanan antar bagian dalam direktorat penyelenggara ibadah haji dan umroh. Keoptimalan kerja unit, konsistensi proses dan data, kemudahan dalam integrasi dengan pihak-pihak di luar direktorat jendral penyelenggaraan ibadah haji dan umrah tetapi masih dalam kaitan dengan pelayanan penyelenggara ibadah haji antara lain bank, penerbangan, imigrasi, dan kedutaan arab saudi

Dengan adanya Sisten Komputerisasi Haji Terpadu yang optimal, tepat guna, dan sasaran serta didukung infrastruktur yang handal di tingkat Kantor Pusat, Provinsi, Kabupaten/Kota, Arab Saudi, Pemvisaan, dan Switching yang menghubungkan denga pihak lain.

Sistem Komputerisasi Haji Terpadu (SISKOHAT) Gen.2 sudah berbasis GUI (Graphical User Interface) dan teknologi berbasis Java Web yang akan lebih memudahkan user (Brainware) untuk berinteraksi dengan sistem dan memperbaiki kekurangan yang ada pada sistem sebelumnya baik secara fitur Software maupun Hardware.

Selain itu dalam rangka optimalisasi pengelolaan serta penyediaan Sistem Informasi dan Komputerisasi Haji Terpadu (SISKOHAT) yang berorientasi pada taat asas dan kinerja maka Kementerian Agama memandang perlu menyusun suatu Standar Operasional Prosedur (SOP). Penyusunan SOP SISKOHAT dimaksudkan sebagai suatu kesatuan dalam dokumen Standar Manajemen Mutu (SMM) penyelenggaraan ibadah haji dan umroh, yang di harapkan nantinya bagian dari persyaratan untuk memperoleh ISO 9001:2008. SOP disusun dalam rangka menjadi acuan untuk melaksanakan tugas secara efektif dan efisien.

Dengan demikian pengelolaan Sistem Informasi dan Komputerisasi Haji Terpadu (SISKOHAT) benar-benar dapat terlaksana tepat sesuai dengan tujuan yang diharapkan sebagai pendukung keberhasilan penyelenggaraan ibadah haji dan umroh baik di Tanah Air maupun di Arab Saudi sekaligus dapat menjadi standar petunjuk penilaian keberhasilan pelayanan berdasarkan indikator kinerja menuju terwujudnya tata kelola kepemerintahan yang baik (good governance).

Sistem Informasi dan Komputerisasi Haji Terpadu (Siskohat) merupakan unsur penyangga berbagai jenis pelayanan ibadah haji. Siskohat sebagai jantung penyelenggaraan ibadah haji yang telah mengintegrasikan elemen-elemen terpenting dalam penyelenggaraan ibadah haji, yakni pendaftaran haji, dokumen haji dan keuangan haji. Tingginya jumlah pendaftar di tiap-tiap daerah 
menyebabkan fungsi siskohat semakin vital.

Sistem informasi dan komputerisasi haji terpadu dinilai efektif dan mempunyai nilai aplikatif yang tinggi apabila sistem tersebut mampu memberikan kontribusi nyata dalam memperlancar pelayanan penyelenggaraan ibadah haji dan umroh di Kementerian Agama yang meliputi :

Berdasarkan hasil wawancara dengan bapak Amri Yusri, selaku Staff Seksi Penyelenggaraan Haji dan Umrah pada tanggal 30 Maret 2018, beliau memaparkan bahwa:

“.....Signifikansi informasi. Sistem Informasi dan Komputerisasi Haji Terpadu ibarat darah segar yang mengalir dalam tubuh pelayanan penyelenggaraan ibadah haji di Kementerian Agama. Banyaknya calon jamaah haji dari berbagai latar belakang yang mendaftar pada tiap tahunnya menuntut Kementerian Agama memberikan pelayanan optimal serta informasi yang akurat yang dapat diakses dengan mudah oleh berbagai pihak. Hal ini diharapkan mampu memudahkan para calon jamaah haji dalam mengakses informasi kapanpun, dimanapun sehingga tidak perlu membutuhkan banyak waktu untuk sekedar menanyakan informasi kepastian pemberangkatan, persyaratan pendaftaran ataupun kepentingan informasi lainnya. Karna pada dasarnya fungsi utama informasi adalah menambah pengetahuan serta mengurangi ketidakpastian pemakai informasi dalam mendapatkan informasi tentang pelayanan penyelenggaraan ibadah haji dan umroh" (wawancara pada hari Jum'at, 30 Maret 2018)

Validitas informasi yang diterima. Calon jamaah haji sangat terbantu dengan adanya penyempurnaan pelayanan yang semakin meningkat tiap tahunnya. Sistem Informasi dan Komputerisasi Haji Terpadu (SISKOHAT) mempermudah para jamaah dalam melakukan semua aktifitas yang berkaitan dengan sistem pelayanan ibadah haji mulai dari pendaftaran ibadah haji, pengeluaran nomor porsi, informasi tahun keberangkatan yang dapat diakses kapanpun dan dimanapun melalui website resmi Kementerian Agama. Informasi yang disajikanpun sangat terpercaya sehingga calon jamaah haji merasa tidak poerlu menghabiskan banyak waktu untuk sekedar mencari info tahun keberangkatan dan info-info lain yang menyangkut pelayanan penyelenggaraan ibadah haji dan umroh

Informasi yang tepat waktu. Merupakan informasi yang tiba pada manajer/pengambil keputusan sebelum suatu keputusan diambil. Seperti halnya keputusan pengeluaran nomor porsi, informasi yang diterima terkait informasi data calon jamaah haji hingga informasi dari Bank Penerima Setoran awal haji tepat pada waktu yang dibutuhkan

Tahapan yang kedua dari proses optimalisasi yakni Unit Software. 
Menurut Onong Uchjana Effendy (1989: 126) Software adalah seluruh faset dari sistem pengolahan data dari luar mesin komputer dan peralatan lainnya yang termasuk hardware. Tanpa software, proses komputerisasi tidak mungkin berjalan.

Unit Software yang selalu digunakan oleh Siskohat adalah Siskohat Gen.2, software ini adalah pengembangan dari Siskohat Gen.1 yang versi lama, dimana ada beberapa fitur yang baru dan fitur yang yang dioptimalkan kinerjanya.

Gambar 1

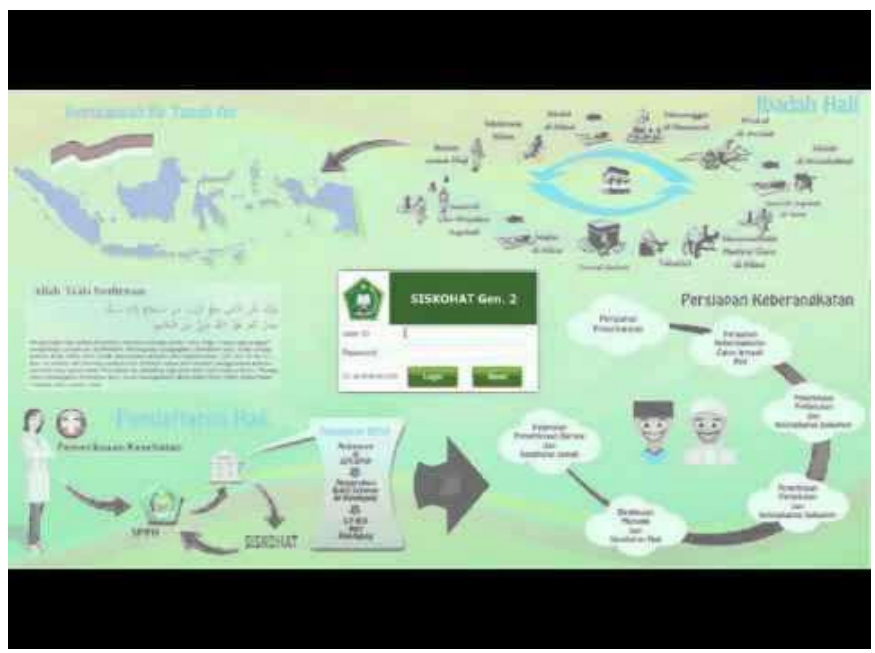

Sumber: Siskohat Generasi 2 Kementrian Agama RI

Softaware, SISKOHAT Gen-2 adalah salah satu software yang digunakan oleh petugas SISKOHAT saat ini. SISKOHAT Gen-2 diluncurkan secara resmi tanggal 3 April 2014. Sistem Komputerisasi terbaru ini merupakan perbaikan dari sistem sebelumnya yaitu SISKOHAT Gen-1. SISKOHAT Gen-2 ini memiliki kelebihan yaitu sudah bisa diakses oleh 420 Kabupaten/kota di Indonesia, khususnya Jawa Barat. Fitur-fitur dalam software SISKOHAT Gen-2 ada beberapa fitur yang baru seperti fitur Monitoring Pendaftaran SPPH, Pembatalan Pemberangkatan, dan lain-lain. Fitur lama yang ada di SISKOHAT Gen-1 terus di optimalkan di SISKOHAT Gen-2.

Tidak hanya di Kanwil Kemenag Provinsi saja yang menggunakan Software ini akan tetapi seluruh Kemenag Kota/Kabupaten memakai Software Siskohat Gen.2 ini. Siskohat Gen.2 ini terintegrasi dengan seluruh penggunanya, baik itu di Siskohat Pusat, Provinsi, dan Kemenag Kota/Kabupaten.

Konsep SISKOHAT Gen I adalah membantu pengelolaan dan manajemen data jamaah sekaligus untuk mengelola antrian pendaftar jamaah haji. SISKOHAT ini dibuat karena pada tahun 1990-an pemberangkatan haji hanya tercatat secara manual sehingga ketika ada kejadian besar (mis. Kejadian 
Terowongan Mina) informasi mengenai jemaah simpang siur akurasi datanya tidak dapat dipertanggungjawabkan. Setelah ada SISKOHAT Gen I data jemaah mulai terkoordinir dengan baik karena data jamaah berangkat bersumber pada 1 sumber data.

\section{Unit Brainware}

Tahap Optimalisasi yang ke-3 adalah unit brainware, menurut Effendy (1989: 127), Brainware adalah aspek manusia yang menangani proses komputerisasi. Bahwa aspek ini penting, karena kesalahan informasi yang dihasilkan mesin komputer seringkali disebabkan faktor personalia yang menanganinya, baik yang menangani aspek hardware maupun aspek software.

Aspek Brainware ini salah satu unit yang paling karena alat untuk mengoperasikan hardware dan software adalah brainware. Brainware atau aspek manusia ini yang akan menjalankan, menginput, dan mengendalikan semua sistem (Winarno, 2010: 75).

Unit Brainware yang dibutuhkan Siskohat Kanwil Kemenag Jabar yakni 7 orang pengguna Siskohat. Dimana 7 orang ini, 4 orang pengguna lama, dan 3 orang pengguna baru. Peran Brainware ini sangat vital bagi Siskohat karena semua Sistem Hardware maupun Software dikendalikan oleh Brainware (pengguna). Untuk bisa jadi brainware di siskohat Kementrian Agama Provinsi Jawa Barat telah menetapkan beberapa kualifikasi/syarat yang harus dimiliki oleh calon brainware siskohat.

Pertama, calon brainware siskohat harus bisa mengoperasikan komputer meliputi, Ms Office, bahasa komputer, dan bisa mempelajari aplikasi siskohat dengan cepat. Kedua, calon brainware harus siap beradaptasi dengan para pegawai/brainware lain agar komunikasi bisa terjalin dan pekerjaan bisa cepat disesaikan.

Menurut hasil wawancara dengan bapak Haikal, ST selaku pegawai siskohat pada tanggal 30 maret 2018, beliau mengatakan bahwa:

"...untuk menjadi brainware siskohat harus mempunyai skill dasar komputer dulu, dan juga mahir bahasa inggris akan memudahkan brainware untuk menjalankan aplikasi siskohat, ketika terjadi error sistem atau hardware, brainware bisa langsung tahu apa yang rusak dan tindakan apa yang harus dilakukan"

Ketika terjadinya error pada sistem Sikohat unit Brainware ini menjadi solusi untuk mengatasi atau meminimalisir error sistem tersebut, dengan kualifikasi Brainware yang sudah ditetapkan oleh Bidang Haji dan Umroh, menjadikan para pengguna Siskohat bisa lebih ahli dan handal dalam Sistem Komputer khususnya Sistem SiskohatUnit-unit dalam sebuah Sistem Komputer seperti, Input Unit, Proses Unit, dan Output Unit, yang menjadi titik inti dari 
pembahasan ini. Ketiga Sikllus ini yang dilakukan Kementrian Agama Provinsi Jawa Barat Bidang Haji dan Umroh khususnya SISKOHAT dinilai sudah baik dan optimal.

Brainware, Pengguna SISKOHAT dari tahun ke tahun telah melakukan regenerasi user, dimana user-user SISKOHAT lama telah melakukan regenerasi kepada user-user muda dan lebih bisa menguasai Software Siskohat. Kementrian Agama Provinsi Jawa Barat Khususnya Bidang Haji dan Umroh telah menetapkan Kompetens-kompetensi yang harus dimiliki oleh user SISKOHAT, seperti menguasai Ilmu Komputer (Informastika), Microsft, dan lain-lain. Tujuan Kementrian Agama Provinsi Jawa Barat menetapkan kompetensi seperti itu agar user SISKOHAT tidak kesusaha dalam mengoprasikan Software/Aplikasi SISKOHAT Gen-2, juga akan meningkatkan kualitas pelayanan bagi Jamaah Haji.

\section{PENUTUP}

Berdasarkan temuan dari penelitian yang telah dilaksanakan dan dibahas pada bab-bab sebelumnya, penulis dapat mengambil kesimpulan dari masalah yang penulis bahas yaitu tentang optimalisasi sistem haji terpadu dalam pelayanan pendaftaran jamaah haji, berdasarkan data yang penulis peroleh maka dapat di ambil kesimpulan sebagai berikut:

Pertama, Unit Hardware yang dilakukan oleh Siskohat Kantor Wilayah Kementrian Agama Jawa Barat yakni, dengan mengupdate komponenkomponen Hardware dengan versi terbaru dengan tujuan untuk mempermudah dan mempercepat kinerja Software dan Brainware, jadi dalam melakukan pelayanan Jamaah Haji bisa semakin optimal dan cepat dalam melayani.

Kedua, Unit Software yang dilakukan oleh Siskohat Kantor Wilayah Kementerian Agama Jawa Barat yakni, dengan mengupdate versi Siskohat dari Gen.1 ke Gen.2 yang mempunyai fitur semakin mudah dan graphic yang lebih modern menjadikan Siskohat Software yang modern dan fleksibel untuk digunakan. Cara Siskohat Kantor Wilayah Kementerian Agama Jawa Barat mengatasi error-error di sistem siskohat yakni denan cara mereport bagian sistem yang error ke Siskohat Pusat cara ini dinali optimal melihat Siskohat sendiri bukan produk asli dari Kemenag Jabar melainkan produk Kemenag Pusat.

Ketiga, Unit Brainware yang dilakukan oleh Siskohat Kementerian Agama Provinsi Jawa Barat yakni dengan cara mempertahankan orang-orang (Brainware) yang mengoperasikan Siskohat yang lama dan menambah tenagatenaga muda yang berkompeten di bidang Ilmu Komputer dan juga menguasai Software Siskohat, cara ini dibilang bisa mengoptimalkan kemampuan Software Siskohat karena yang mengoperasikan Software Siskohat adalah orang-orang yang ahli di bidang Komputer. 
Berdasarkan hasil dari pemaparan kesimpulan di atas, maka penulis akan memberikan sedikit saran terkait optimalisasi sistem komputerisasi haji terpadu yang dilakukan oleh seksi Penyelenggaraan Haji dan Umrah dalam upaya pelayanan pendaftaran jamaah haji, yaitu: 1) Sosialisasi kepada calon jamaah Haji Reguler maupun Khusus, masih banyak Calon jamaah yang bingung untuk mendaftar karena minimnya informasi dan ketidaktahuan jamaah untuk mengakses infromasi di webstie kemenag ataupun yang lain. 2) Perihal sistem komputerisasi peneliti memberikan saran agar komponen-komponen komputer seperti hardware, software maupun brainware, agar terus di update tiap tahunnya karena ketiga komponen tersebut menunjang keberhasilan atau ke optimalan dalam proses pelayanan pendaftaran Jamaah Haji, bug-bug ataupun error pada sistem software SISKOHAT harus bisa di atasi secara cepat karena sistem SISKOHAT sangat vital apalagi di dalamnya berisi data-data jamaah haji, apabila ada error di sistemnya otomatis data-data jamaah haji bisa terancam hilang. Maintenance adalah solusi alternatif untuk mengatasi hal-hal tersebut.

\section{DAFTAR PUSTAKA}

Aziz, A. (2007). Ibadah Haji Dalam Sorotan Publik, Jakarta: Puslitbang Kehidupan Keagamaan

Budiarti, (1999). Sistem Informasi Manajemen, Mondial, Jakarta

Departemen Agama Direktorat Jenderal, (2009). Undang-undang RI Nomor 13 Tabun 2008 Tentang Penyelenggaraan Ibadab Haji, Jakarta

Departemen Pendidikan dan Kebudayaan. (2005). Kamus Besar Bahasa Indonesia : Jakarta Balau Pustaka

Effendy, O. U. (1989). Sistem informasi manajemen, Bandung: Mandar Maju, Fajar, L. (2008). Manajemen Pemasaran. Yogyakarta: Penerbit Graha Ilmu

Jogiyanto, H. M. (1999). Analisis dan Desain Sistem Informasi : Pendekatan Terstruktur

Teori dan Praktek Aplikasi Bisnis, ANDI Yogyakarta, Yogyakarta

Nidjam, \& Hanan, A. (2001). Manajemen Haji, Zikrul Hakim, Jakarta, Sigit, P. W. (1999). Analisis dan Perancangan Sistem, Mondial, Jakarta

Ratminto, \& Atik, S. W. (2007). Manajemen Pelayanan. Yogyakarta: Pustaka Belajar.

Murdik, R. G. (2003), Analisis dan Desain Sistem Informasi, Yogyakarta: Andi.

Sanusi, I. (2018). Networking Badan Amil Zakat Nasional Jawa Barat dalam Meningkatkan Pelayanan Zakat. Ilmu Dakwah: Academic Journal For Homiletic Studies, 10(1), 79-96.

Shihab, M. Q. dkk. (2000). Sejarah dan 'Ulum al-Qur'an, Jakarta, Pustaka Firdaus.

Syari'ati, A. (1994). Ideologi Kaum Intelektual Suatu Wawasan Islam, Bandung: 
A. F. Zulfa, I. Sanusi, A.I. Setiawan

Mizan.

Winardi, (1996). Perilaku Organisasi (Organizational Behaviour). Bandung : Tarsito.

Winarno, E, (2010). 40 Tip Perawatan dan Optimasi Perangkat Keras Komputer, Jakarta: Elex Media 